\title{
КОНЦЕПТУАЛЬНО-ТЕХНОЛОГІЧНІ ПІДХОДИ В СТВОРЕННІ ЄДИНОГО МЕДИЧНОГО ОСВІТНЬОГО ПРОСТОРУ
}

О. П. Мінцер

Національна медична академія післядипломної освіти імені П. Л. Шупика

Проаналізовано технологічні співвідношення створення єдиного освітнього простору й єдиного освітнього середовища. Запропоновано характеристики проектування єдиного освітнього простору, що включають активність простору, пертинентність контенту й ефективність використання єдиного інформаційного освітнього простору. Розглянута типова структура єдиного інформаційного освітнього простору, що складається з трьох основних елементів: системи управління навчальним процесом, засобів для перевірки (тестування) засвоєння навчального матеріалу та системи управління діяльністю викладачів із структуруванням навчального матеріалу.

Ключові слова: єдиний інформаційний освітній простір, єдине інформаційне освітнє середовище, проективна педагогіка, конструктивна педагогіка, тезаурусні кластери, хмарні обчислення.

\section{КОНЦЕПТУАЛЬНО-ТЕХНОЛОГИЧЕСКИЕ ПОДХОДЫ В СОЗДАНИИ ЕДИНОГО МЕДИЦИНСКОГО ОБРАЗОВАТЕЛЬНОГО ПРОСТРАНСТВА}

\begin{abstract}
О. П. Минцер
Национальная медицинская академия последипломного образования имени П. Л. Шупика

Проанализированы технологические соотношения создания единого образовательного пространства и единой образовательной среды. Предложены характеристики проектирования единого образовательного пространства, включающие активность пространства, пертинентность контента и эффективность использования единого информационного образовательного пространства. Рассмотрена типовая структура единого информационного образовательного пространства, состоящая из трех основных элементов: системы управления учебным процессом, средств для проверки (тестирования) усвоения учебного материала и системы управления деятельностью преподавателей по структурированию учебного материала.
\end{abstract}

Ключевые слова: единое информационное образовательное пространство, единая информационная образовательная среда, проективная педагогика, конструктивная педагогика, тезаурусные кластеры, облачные вычисления.

\section{CONCEPTUALLY-TECHNOLOGICAL APPROACHES IN THE CREATION OF A SINGLE INTEGRATED MEDICAL EDUCATIONAL SPACE}

\section{O. P. Mintser}

\section{Shupyk National Medical Academy of Postgraduate Education}

It was analyzed technological relations of creation a common educational space and a unified educational environment. It has proposed design features a single educational space, including space activity, pertinence and effectiveness of using content in IIES. Typical structure of IIES was described. It consists of three main elements: learning management system, tools for checking (testing) Learning and Management System of the teachers' activities in the structuring of educational material.

Key words: integrated information educational space, integrated information educational environment, projective pedagogy, constructive pedagogy, thesaurus clusters, cloud computing.

Вступ. Безумовною метою створення єдиного освітнього простору (ЄОП) є сприяння безперервному професійному розвитку лікарів і провізорів.
Концептуально та структурно ЄОП забезпечується сучасними інформаційними технологіями і засобами телекомунікаційного зв'язку. Зрозуміло, що в

(c) О. П. Мінцер 
основу створення сдиного освітнього простору мас бути покладена і модель сучасної освіти, особливо іiі технологічна складова $[1,2,3]$.

Раніше нами висловлено думку, що, хоча ЄОП $\epsilon$ розвитком освітнього середовища, індивідуалізація освіти неможлива без зворотного процесу - виділення в освітньому просторі віртуального освітнього середовища, яке має характер локальної або індивідуальної сфери передавання знань. Стратегія створення подібного середовища до тепер не розроблена

Мета дослідження: обгрунтувати шляхи побудови та принципи оптимізації єдиного освітнього середовища.

Концептуалізація дослідження. Технологічно модель освіти повинна забезпечити інтеграцію різних способів освоєння предмета, розкрити та збільшити творчий потенціал людини для вільних і осмислених дій, цілісного сприйняття й усвідомлення світу, впровадження інноваційних процесів у систему масової освіти. Ще однією особливістю сучасної освіти слід визнати істотне підвищення ролі самоосвіти та коригуючих функцій викладача. У цих умовах основним завданням системи освіти стає виховання творчої особистості з критичним мисленням.

Введемо ряд визначень. Під єдиним освітнім простором в системі безперервної медичної освіти будемо розуміти спільність принципів політики з підготовки лікарів і провізорів, узгодженість освітніх стандартів, програм та вимог із підготовки та атестації наукових і науково-педагогічних кадрів та програм, забезпечення рівних можливостей і вільної реалізації прав громадян на здобуття освіти в освітній установі.

Інформаційна революція зумовила створення єдиного інформаційно-освітнього простору (ЄІОП). Будемо розуміти під ним керовану систему передавання знань, що динамічно розвивається. В технологічному плані ЄІОП являє собою системний інформаційно-технологічний модуль, що включає матеріально-технічні, інформаційні та кадрові ресурси, забезпечує автоматизацію управлінських і педагогічних процесів, узгоджене оброблення, передавання та зберігання інформації, наявність нормативноорганізаційної бази, технічного та методичного супроводу. СІОП на технологічному рівні передбачає комплекс електронних навчальних систем, баз знань різного змісту, систем комп'ютерних телекомунікацій і мережевої взаємодії, інтегрованих педагогічних технологій, інструментів дистанційного моніторингу та управління, до якого забезпечено доступ кори- стувачів за допомогою мережевих технологій відповідно до їх статусу.

Нарешті, під єдиним інформаційним освітнім середовищем (СIOC) розуміємо сукупність інформаційних освітніх рішень, заснованих на загальних правилах і підходах до освітніх програм і послуг, оновлення форм, засобів, технологій і методів реалізації освітніх програм і послуг, викладання дисциплін і розповсюдження знань. По суті, EIOC - це загальна інформаційна освітня система електронних освітніх ресурсів, інформаційних освітніх сервісів, засобів, технологій, що створена на загальній програмно-апаратній платформі та служить інтегрованим середовищем для всіх учасників освітнього процесу.

Освітнє середовище $\epsilon$ частиною освітнього простору, її специфічними особливостями є об'єднання впливів та умов формування особистості, різних шляхів освоєння навчального матеріалу. Саме освітнє середовище дозволяє забезпечити регіональні й особистісні особливості освітнього процесу, припускаючи об'єднання загальних, особливих та індивідуальних завдань навчання. Порівнюючи визначення освітнього середовища та освітнього простору, легко помітити, що в їх дефініщіях є багато точок дотику, в першу чергу це спрямованість на завдання освіти. Проте поняття освітнього середовища розуміємо узагальнено, як набір технологій, що включають різні зв'язки та взаємодії людини з реальним світом практичної медицини. Зрозуміло, межі соціального просторово-предметного оточення людини (групи людей, колективу) проникні, та середовище представляється “ймовірнісним" i “надлишковим”.

Розглянемо сутність і етапи процесу створення та функціонування єдиного інформаційного освітнього простору в концепції медичного безперервного професійного розвитку (БПР).

Результати та їх обговорення. Конструюючи освітній простір вважаємо за необхідне, насамперед, обгрунтувати характеристики, на підставі яких можна буде визначити його ефективність.

Однісю з основних характеристик ЄІОП вважасмо його активність (А). Під нею розуміється частота звернень суб'єкта навчання за необхідною інформацією. Практична важливість даного показника особливо зростає при ідентифікації регіонального або локального освітнього середовища. Активний виховний простір чудовий тим, що забезпечує кожного суб' єкта навчання можливістю своєчасного аналізу нових технологій і явищ. Зрозуміло, створення подібного простору підкреслює особливу роль викладача. 
Іншою важливою характеристикою вважаємо пертинентність отримуваної інформації - $\tau$. Вона оцінюється шляхом обчислення відношення частоти запитів за даними дескриптора в різних кластерах освітнього контенту до числа пошукових кластерів, a саме:

$$
\tau_{z}=\frac{\sum_{j=1}^{S} \tau_{j}^{n}}{S},
$$

де $S$ - число пошукових кластерів.

Третім показником при проектуванні освітнього простору вважаємо його ефективність, $E_{i}, i=1,2, \ldots$, I (де $i$ - освітній модуль), що визначається за зміною результатів тестування знань заданого модуля (зрозуміло при модельних контрольних дослідженнях, що блокують використання інших ресурсів) при використанні заданого контенту простору та фіксуванні часу знаходження в ньому.

Певні зміни в систему понять, що формується, внесло розширення технологій віртуальної інтеграції освітніх установ і подальше створення віртуальних освітніх інформаційних середовищ $[1,6]$. Вони дозволили на основі використання нових інформаційних технологій підвищити якість системи безперервної освіти шляхом індивідуалізації трансферу знань. Хоча, очевидно, що створення інформаційного освітнього середовиша все ж має регіональний або локальний характер. Тим не менш, подібні процеси зумовили істотну трансформацію поняття ЄІОП останнім часом

Віртуальний освітній простір, створюваний на основі інформаційно-комп'ютерних технологій, повинен не тільки підтримувати розвиток особистості суб' єкта навчання в традиційних освітніх практиках, але й максимально сприяти формуванню в нього соціокодів інформаційного суспільства.

Аналіз тенденцій розвитку сучасних освітніх систем дозволяе представити структуру у вигляді трьох основних складових.

Основним елементом СІОП $є$ система управління навчальним процесом - СУНП (в англомовній літературі LMS - Learning management system). Під СУНП далі будемо розуміти систему для розроблення й управління навчальним контентом, забезпечення онлайн доступу до нього, контролю засвоєння матеріалу суб'єктом навчання, оцінювання трансферу знань. Для слухача в системі безперервного професійного розвитку лікарів і провізорів у навчальному середовищі обов' язково повинні бути присутніми такі елементи: ресурси (будь-які навчальні матеріали з різними форматами надання інформації); засоби для спілкування суб'єктів навчання між собою та $з$ викладачем, а також обговорення навчальної діяльності.

Важливо мати інструментарій для організації індивідуального або групового навчання, а також розподіленого за часом доступу суб'єктів навчання до ресурсів навчального середовища. Зауважимо, шо від ергономіки навчального середовища багато в чому залежить якість освітніх практик.

Окремої уваги заслуговують засоби для перевірки (тестування) засвоєння навчального матеріалу. Вони припускають використання не тільки самоперевірки знань, а й поточних і контрольних перевірок, контролю траєкторії навчання, виявлення індивідуальних творчих потенцій, точок біфуркації освітньої траєкторії тощо.

Третім елементом системи є система управління діяльністю викладача зі структурування навчального матеріалу, його розміщення в освітньому просторі. В цьому відношенні найважливішої ролі набувають онтологічні моделі знань. Вкрай важливо забезпечити постійний моніторинг активності використання ЄІОП (так само як і інших характеристик простору) для своєчасної корекції контенту, його структури й оновлень.

Отже, розглядаючи реальні шляхи побудови та принципи єдиного освітнього середовища, необхідно таким чином забезпечити використання основних компонентів ЄІОП, щоб забезпечити індивідуалізацію освіти за визначеною викладачами «навчальною траєкторією», використання сформованих баз даних та інформаційних ресурсів, можливість пошуку новітньої інформації для забезпечення як професійної, так і наукової та проблемно-пошукової діяльності. Структурно функціонування ЄІОП забезпечують відповідні сервери та мережеве обладнання, можливо обчислювальні кластери та ГРІД-мережа. Системи з інтелектуальним ядром можуть бути використані для комп'ютерного моделювання. Комунікація суб' єктів навчання з колегами та викладачами здійснюється за допомогою сервісів та Інтернет-ресурсів. Іншими структурними компонентами СІОП можна вважати комунікативний, соціально-утилітарний (використання корпоративної інформації), когнітивний, креативний (проблемно-пошукова діяльність). Відзначимо, що забезпечення особистісної підготовки суб' єктів навчання детермінується соціальним конструктивізмом.

Входження в єдиний простір потребує принципово нового змісту методик освіти, нового методично- 
го забезпечення. Найістотнішими в методиці стануть такі зміни, як перехід до інтегрованого навчання в контексті досліджуваного предмета, перенесення акцентів під час навчання з пошуку вірних відповідей на розвиток уміння вирішувати проблеми; заміна пасивного типу навчання на активний; збільшення ролі самоконтролю знань.

Важливе значення має забезпечення суб' сктам безперервної медичної (фармацевтичної) освіти проведення необхідних «хмарних обчислень» [10]. Добре відомо, що швидкий розвиток засобів математичного моделювання медичних, біологічних, фармацевтичних процесів вимагає від сучасного фахівця можливості кількісної (на підставі моделі) перевірки ефективності діагностичних і лікувальних заходів. Іншими словами, важливо надати суб' єктам навчання можливість зручного доступу за допомогою мережі до загального пулу з налаштованими обчислювальними ресурсами (наприклад мережі, сервера, системи зберігання, додатків, послуг). Підкреслимо, що сучасні уявлення про модель хмари стверджують, що вона сприяє доступності новітніх додатків і

\section{Література}

1. Кремень В. Г. Освіта та наука в Україні - інноваційні аспекти. Стратегія. Реалізація. Результати / В. Г. Кремень. - К. : Грамота, 2005. -448 с.

2. Перспективні освітні технології : наук.-метод. посіб. / заг. ред. Г. С. Сазоненко / [А. М. Алексюк, І. Д. Бех, Т. Ф. Демків та ін. ]. - К. : Гопак, 2000. - 560 с.

3. Федорук П. И. Исследование эффективности функционирования адаптивной системы дистанщионного обучения EduPro / П. И. Федорук // УСиМ. - 2009. - № 6. C. 64-70.

4. Гапонова В. М. Принципи та функції педагогічного тестового контролю / В. М. Гапонова, Л. С. Рабійчук // Збірник науюових праць. - Хмельнишький : Вид-во Національної академії ПВУ, 2002. - Ч. ІІ, № 20. - С. 91-96. 5. Захожай В. Б. Статистичне забезпечення управління якістю : навч. посіб. для ВНЗ / В. Б. Захожай, А. Ю. Чорний. - К. : ЦУЛ, $2005 .-340$ с.

6. Computational Intelligence in Web-based Education: A Tutorial / T. Vasilakos, V. Devedzic, Kinshuk [et al.] // Journal of Interactive Learning Research (JILR). - 2004 - Vol. 15, № 4. - P. 299-318.

7. Soller A. A computational approach to analysing online knowledge sharing interaction / A. Soller, A. Lesgold / [eds. характеризується п'ятьма основними елементами (самообслуговуванням на вимогу, широким доступом до мережі, об'єднаним ресурсом, незалежним розташуванням, швидкою гнучкістю, вимірюваними сервісами). Хмара, як правило, містить три сервісні моделі (програмне забезпечення як послуга, платформа як послуга, інфраструктура як послуга) і чотири моделі розгортання (приватні хмари, групові хмари, громадські хмари, гібридні хмари).

Висновки. 1. ЄІОП медичних вищих навчальних закладів, що формується, слід розглядати як єдиний структурно-динамічний процес.

2. Запропоновано характеристики проектування єдиного освітнього простору, шо включають його активність, пертинентність контенту й ефективність використання ЄІОП.

3. Розглянуто типову структуру ЄІОП, що складається з трьох основних елементів: системи управління навчальним процесом, засобів для перевірки (тестування) засвоєння навчального матеріалу і системи управління діяльністю викладачів зі структурування та розміщення навчального матеріалу.

U. Hoppe, F. Verdejo, J. Kay] // AI-ED'2003. - Amsterdam : IOS Press, 2003. - P. 253-260.

8. Вакарчук І. О. Якість освіти і вільна траєкторія студента/ I. О. Вакарчук // Вісник АН ВО України. - 2009. - № 3 (64). - C. 8-15.

9. Сироджа И. Б. Квантовые модели и методы искусственного интеллекта для принятия решений и управления / И. Б. Сироджа. - К. : Науюова думка, 2002. -428 с.

10. Виноградова Е. А. Создание единого информационно-образовательного пространства в образовательном учреждении. ИКТ - новая технология управления в образовательном учреждении / Е. А. Виноградова. - Режим доступу: http://festival. 1september.ru/articles/538755/.

11. Новые педагогические и информационные технологии в системе образования : учеб. пособ. для студ. пед. вузов и системы повыш. квалиф. пед. кадров / Е. С. Полат, М. Ю. Бухаркина, М. В. Моисеева, А. Е. Петров / под ред. Е. С. Полат. - М. : Академия, 2000. - 272 с.

12. Определение облачных вычислений. Рекомендации Национального Института Стандартов и Технологий (США). - USA : NIST, 2007. - Режим доступу: http:// bourabai.kz/mmt/cloud4.htm. 